\title{
"Analysis of current trends in innovation and investment activity of Ukrainian metallurgical enterprises"
}

\begin{tabular}{|c|c|}
\hline \multirow{4}{*}{ AUTHORS } & Maryna Resler (D https://orcid.org/0000-0002-3787-9472 \\
\hline & Mykola Kurylo iD https://orcid.org/0000-0003-1496-134X \\
\hline & Mykola Logvinenko iD http://orcid.org/0000-0002-5231-3610 \\
\hline & $\begin{array}{l}\text { Vitalii Makhinchuk } \\
\text { Andriy Ivanyshchuk iD https://orcid.org/0000-0001-5396-0388 }\end{array}$ \\
\hline ARTICLE INFO & $\begin{array}{l}\text { Maryna Resler, Mykola Kurylo, Mykola Logvinenko, Vitalii Makhinchuk and } \\
\text { Andriy Ivanyshchuk (2018). Analysis of current trends in innovation and } \\
\text { investment activity of Ukrainian metallurgical enterprises. Investment } \\
\text { Management and Financial Innovations, 15(2), 116-128. } \\
\text { doi:10.21511/imfi.15(2).2018.11 }\end{array}$ \\
\hline DOI & http://dx.doi.org/10.21511/imfi.15(2).2018.11 \\
\hline RELEASED ON & Tuesday, 15 May 2018 \\
\hline RECEIVED ON & Friday, 06 April 2018 \\
\hline ACCEPTED ON & Monday, 07 May 2018 \\
\hline & $(\mathrm{cc})$ EY \\
\hline LICENSE & $\begin{array}{l}\text { This work is licensed under a Creative Commons Attribution } 4.0 \text { International } \\
\text { License }\end{array}$ \\
\hline JOURNAL & "Investment Management and Financial Innovations" \\
\hline ISSN PRINT & $1810-4967$ \\
\hline ISSN ONLINE & $1812-9358$ \\
\hline PUBLISHER & LLC "Consulting Publishing Company "Business Perspectives" \\
\hline FOUNDER & LLC "Consulting Publishing Company "Business Perspectives" \\
\hline & $\begin{array}{l}= \pm: \\
= \pm:-\end{array}$ \\
\hline NUMBER OF REFERENCES & NUMBER OF FIGURES \\
\hline 30 & 3 \\
\hline
\end{tabular}

(c) The author(s) 2021. This publication is an open access article. 


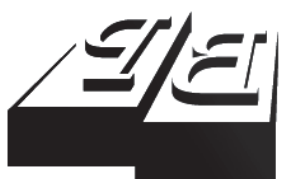

BUSINESS PERSPECTIVES

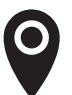

LLC "CPC "Business Perspectives" Hryhorii Skovoroda lane, 10, Sumy, 40022, Ukraine

www.businessperspectives.org

Received on: $6^{\text {th }}$ of April, 2018 Accepted on: $7^{\text {th }}$ of May, 2018

(C) Maryna Resler, Mykola Kurylo, Mykola Logvinenko, Vitalii Makhinchuk, Andriy Ivanyshchuk, 2018

Maryna Resler, D.Sc. (Economics), Professor, Head of Department of Accounting, Taxation and Marketing, Mukachevo State University, Ukraine.

Mykola Kurylo, D.Sc. (Law), Professor, Sumy National Agrarian University, Ukraine.

Mykola Logvinenko, Associate Professor, Chair of Administrative, Economic Law and Financial and Economic Security, Educationalscientific Institute of Law, Ukraine.

Vitalii Makhinchuk, D.Sc. (Law), F. H. Burchak Scientific Research Institute of Private Law and Entrepreneurship of National Academy of Law Sciences of Ukraine, Ukraine.

Andriy Ivanyshchuk, D.Sc. (Law), Research Institute of Public Law, Kyiv, Ukraine.

\section{(c) (1)}

This is an Open Access article, distributed under the terms of the Creative Commons Attribution 4.0 International license, which permits unrestricted re-use, distribution, and reproduction in any medium, provided the original work is properly cited.
Maryna Resler (Ukraine), Mykola Kurylo (Ukraine), Mykola Logvinenko (Ukraine), Vitalii Makhinchuk (Ukraine), Andriy Ivanyshchuk (Ukraine)

\section{ANALYSIS OF CURRENT TRENDS IN INNOVATION AND INVESTMENT ACTIVITY OF UKRAINIAN METALLURGICAL ENTERPRISES}

\begin{abstract}
The current stage of the socio-economic development of the Ukrainian economy is characterized by an imperfect economic base, low level of labor productivity, high resource intensity and energy consumption of production. It is the result of insufficient innovation and investment activity - a leading factor in the growth of competitiveness and a serious obstacle in the conditions of increasing openness of the economy, joining the country to the processes of globalization. This also applies to the development of the metallurgical industry, which is one of the basic branches of the national economy, since its production and export potential largely determine the stability of the economy and the filling of the budget of the country.

The article analyzes the influence of financial and administrative analysis on the managerial, financial and investment activity of the metallurgical industry, which enables to assess and determine the innovation and investment level of the metallurgical industry and to analyze the structure of world steel production.

It should be mentioned that although such parts of economic analysis as financial and administrative are deepening and complement each other, they should be considered separately, because it will allow to improve organizational, informational and methodological assurance, based on methodological approaches and considering practical needs.
\end{abstract}

Keywords

JEL Classification investment development, innovation activity, economic analysis, assets, metallurgical enterprises, Ukraine

E22, L61, O30

\section{INTRODUCTION}

In modern conditions, there are rapid changes in the technological mode of production, economic structure, the nature of economic growth, values and motivations, perceptions of the criteria of social progress.

Among the main problems of Ukraine's innovation development are:

1) lack of real mechanisms for pooling existing resources and their concentration on the most significant and promising areas of development;

2) absence of a relationship between the increase in sales by private companies and the increase in funding for research and development carried out by them;

3) lack of clear orientation of innovation policy to address specific economic problems of regions and their restructurings, considering market factors; 
4) significant duration of the registration procedure of the innovation project, which does not encourage legal entities and individuals before it passes.

Nowadays the issue of implementing a new innovation policy is a crucial prerequisite for industrial development of metallurgical enterprises. The central point in the strategy of innovation activity of the enterprise is its existing innovative potential, which depends on the effectiveness of the implementation of innovation strategy, as well as the efficiency of the operation of the entire organizational and economic mechanism of innovation activity of the enterprise.

The problem of the analysis of innovation and investment activity of metallurgical enterprises is extremely relevant, since the economic potential of society characterizes only the general status without revealing the nature of processes occurring directly in industrial enterprises. It is necessary to have objective information and trends in the development of the industry, both world and domestic, in order to construct the forecasts and develop the strategies for the development and adoption of effective managerial decisions at enterprises. Therefore, the differentiation of economic analysis into financial and managerial is relevant and at the same time dubious. The importance and necessity of the study of this issue is determined by the lack of organizational, methodological and informational security of both types of analysis and requires a scientific approach to the solution of this problem.

\section{LITERATURE REVIEW}

Despite significant scientific achievements in the field of the theory and methodology of financial and managerial analysis, covered in the works of many economists, there is no single approach to the allocation of such types of analysis and their influence on the innovation and investment activity of metallurgical enterprises.

Differentiation of the analysis of economic activity of the enterprise into managerial and financial character is determined, in particular, by the differentiation of accounting into management and finance.

However, such an approach to the allocation of these types of economic analysis is not supported by all economists. Thus, in particular, in the monograph on accounting, control and analysis in international business, the authors point out that "it is impossible to divide the accounting system to managerial and not managerial (financial) ones. Such division is conditional, and there is no scientific or practical significance. Consequently, the division of analysis into two types according to this criterion can't be considered as correct" (Borodkin, 2001; Popovich, 2004).

Of course, the differentiation of economic analysis into financial and managerial can be based on the system of accounting as the main information base used in the implementation of one or another type of analysis. There are a lot of other peculiarities that differentiate the managerial analysis from financial one.

In addition, some economists often identify the financial analysis as external analysis, and managerial as internal. This approach is also illogical, since information obtained through financial analysis is also required by internal users (Kindratska, 2006).

Conceptual model of managerial economic analysis consists of several blocks of analytical tasks: 1) comprehensive managerial analysis, 2) operational managerial analysis, 3) problematic operational analysis, 4) financial managerial analysis (Svichkar, 1999).

Then, Svichkar divides financial managerial analysis into "internal financial analysis and external financial analysis". Considering managerial and financial analyses, it is expedient to determine their place in the overall system of economic analysis. Such an opinion is also supported by Kindratska (2006), Mnyh (2005), Sheremet (2002).

Lakhtionova (2004) states that "under the term "financial analysis" should be understood an external and internal analysis of the results of activity 
and financial state of the enterprise, financial relations, the aggregate of financial resources and their flows in a single production and trade process, and under the term "managerial analysis" - an internal economic analysis (analysis of material, labor resources, analysis of fixed assets, analysis of costs and benefits and cost of production)".

Innovation and the ability to implement the instrument of scientific and technological progress is a prerequisite for the development of the socio-economic complex of the country, which is largely determined by the development of its enterprises. But the ensuring the innovative enterprise development is possible only with sufficient funding and attracting a sufficient amount of investment. Therefore, there is a need to create a mechanism for activating innovation and investment activity of enterprises as metallurgical enterprises, as well as other types of activities.

The world economic literature interpreted the term "innovation" as a potential transformation of scientific and technological progress in real, embodied in new products and technologies. Innovation (English) arose from two words: the first is Latin "innovation" (novelty, innovation) and the second one is English prefix "in", which means "in", "introduction". Consequently, the translation from English "innovation" means the introduction of something new (Mishenin, 1996).

The Law of Ukraine "On Innovation Activity" defines the term "innovation" as newly created (applied) and (or) improved competitive technologies, products or services, as well as organizational, technical, industrial, administrative, commercial or other considerations that significantly improve the structure and quality of production and (or) social sphere (2002).

According to Schumpeter (2008), innovation is the use of new combinations of existing productive forces to solve commercial problems. The author saw them as the source of the development of economic systems. Back in late 60's of the twentieth century, he identified five types of innovations: 1) manufacturing of a new product which is not known to consumers or a product with qualitatively new properties; 2) introduction of a new means of production; 3) development of a new market of a particular industry of the country; 4) finding new sources of raw materials and semifinished products; 5) application of new organizational forms.

Twice (1989) defines the innovation as a process in which the invention or idea becomes economically significant. Sahal (1985) considers innovations as elements that remove from the equilibrium the entire economic system. They are accompanied by persistent fluctuations, which are prolonged by the extended action of some radical innovations. Drucker (2008) defines innovation as a specific entrepreneur tool that provides resources to new wealth creation opportunities. Medinsky, Shakurova (1997) state that the innovation is an object that has been introduced into production as a result of a scientific research or a discovery, which is qualitatively different from the previous counterpart. Dykha, Tanasiienko, and Kolisnyk (2017) consider the introduction of innovations as the key factor in the growth of labor productivity. Shtuler, Cherlenyak, Domyshche-Medyanik, and Voitovych (2017) allocate innovative processes as a key aspect of competitiveness in the global economy. Fathutdinov (2002) states that the innovation is the final result of introduction of innovation to change the control object and obtain economic, environmental, technological or other type of effect.

Consequently, innovation can be interpreted in three aspects:

1) innovation in the broad sense - as any change that increases the competitiveness of business entities;

2) innovation in the narrow sense - as a process of transformation of scientific achievements into production;

3) innovation, which is introduced in economic practice.

So, the innovation is any innovation, a new phenomenon or any change, the introduction of which in operation reduces the consumption of natural resources, improves the quality of production, production capacity and competitiveness of the company both in domestic and foreign markets. 
By exploring innovation activity, it is necessary to draw attention on the investment activity of modern enterprises.

The sources of investment resource formation in a market economy are diverse. In the economic literature, four different groups of interpretation of the concept "investment" are distinguished:

1) investments are determined on the basis of payments, that is, through the flow of payments and expenses;

2) investments, which are determined on the basis of property - investments are considered as a process of conversion of capital into objects of property in the balance sheet assets of the enterprise, including securities;

3) combinatorial concept of investments - investments aimed at expansion of business or creation of conditions for increasing the efficiency of its functioning;

4) investments, which are determined on the basis of the dispositional concept - the process of investment, which involves connection with financial means, which reduces the level of their free disposal by the enterprise (Dvornik \& Perupka, 2008).

Among the foreign scholars, whose works investigate the topic of investments, it is necessary to mention Hitman and Sharpe. They focused on investment issues, factors that affect them, as well as the significance and impact of investments on the national and global economy. The most expedient definition of investments is given by the authors of "Economics" K. P. McConnell and S. L. Bru: "This is the cost of building new factories, on machines, equipment with a long service life; costs of production and accumulation of means of production and increase of material stocks; the costs of improving education, health of workers or increasing labor mobility".

In the domestic literature, investment and investment activity are often defined as "a complex of measures and actions of individuals and legal entities that invest their own funds (in material, financial or other property form) in order to generate profit" (Haitsev, 2006). According to the author, investments are monetary, financial, material and intangible assets that are planned to be attracted to a certain type of activity for the purpose of development of any sphere, introduction of modern innovative measures, improvement of the production process, profit making and to achieve social and environmental effects.

Consequently, the economic categories of "investment" and "innovation" exist only in their interrelation, besides, in the context of enterprise development, separate existence of investments and innovations is not possible. This is explained by the fact that innovation is a prerequisite for enterprise development and requires significant investment.

\section{METHODS}

Achievement of the objectives of the article is made by such general and special methods of investigation, analysis and synthesis, generalization and systematization, the dialectical approach.

The purpose of the research is to describe the peculiarities of financial and managerial analysis of innovation and investment activity, studying them as separate types of analysis and interconnections as elements of an integrated management system for metallurgical enterprises.

\section{RESULTS}

The sources of accounting and analytical information are accounting system and analysis. This provides the necessity to set clear definition and justification of the general characteristics of accounting and analytical information for the introduction of innovations and investments in the development of metallurgical enterprises.

The accounting information has its own peculiarities, which makes it very important for management and making the right conclusions. It arises at different stages of accounting technology and solves various accounting tasks:

- each economic process is recorded as a transaction in the primary documents, which is a certain confirmation of its implementation. 
This document is a starting point for further accounting and registration in other documents (accounting registers);

- accounting registers, therefore, after filling, become the carriers of accounting information and play an already significant role for analyzing and obtaining analytical information, after carrying out some mathematical and analytical settlement procedures;

- it is possible to draw up accounting forms, which serve as a certain proof of the business activity of the enterprise on the basis of the compilation of registers.

Essentially, the reports are the main sources of economic analysis and are the most important for management.

Analytical information includes the results of the implementation of the procedures for mathematical and logical processing of forecast, plan- ning, accounting and regulatory information on the given algorithms of calculation, appearing as generalizing one in regard to the other types of information.

Analytical information is a product of economic analysis. At the large enterprise, it is carried out by specially created analytical groups or units led by analysts. The main range of their tasks includes not only the generalization and analysis of the sales, production program, execution of plans, calculation of profitability indicators, creditworthiness, sustainability, etc., but also providing information management on the reliability of partners, buyers, reputation of goods, prices, business project evaluation, analysis of external financial and other kinds of information. That is to say, this is a fairly wide list of issues.

Based on the study, the scheme is built for the formation of accounting and analytical information for enterprises interested in effective management decision-making (Figure 1).

Source: Developed by the authors.

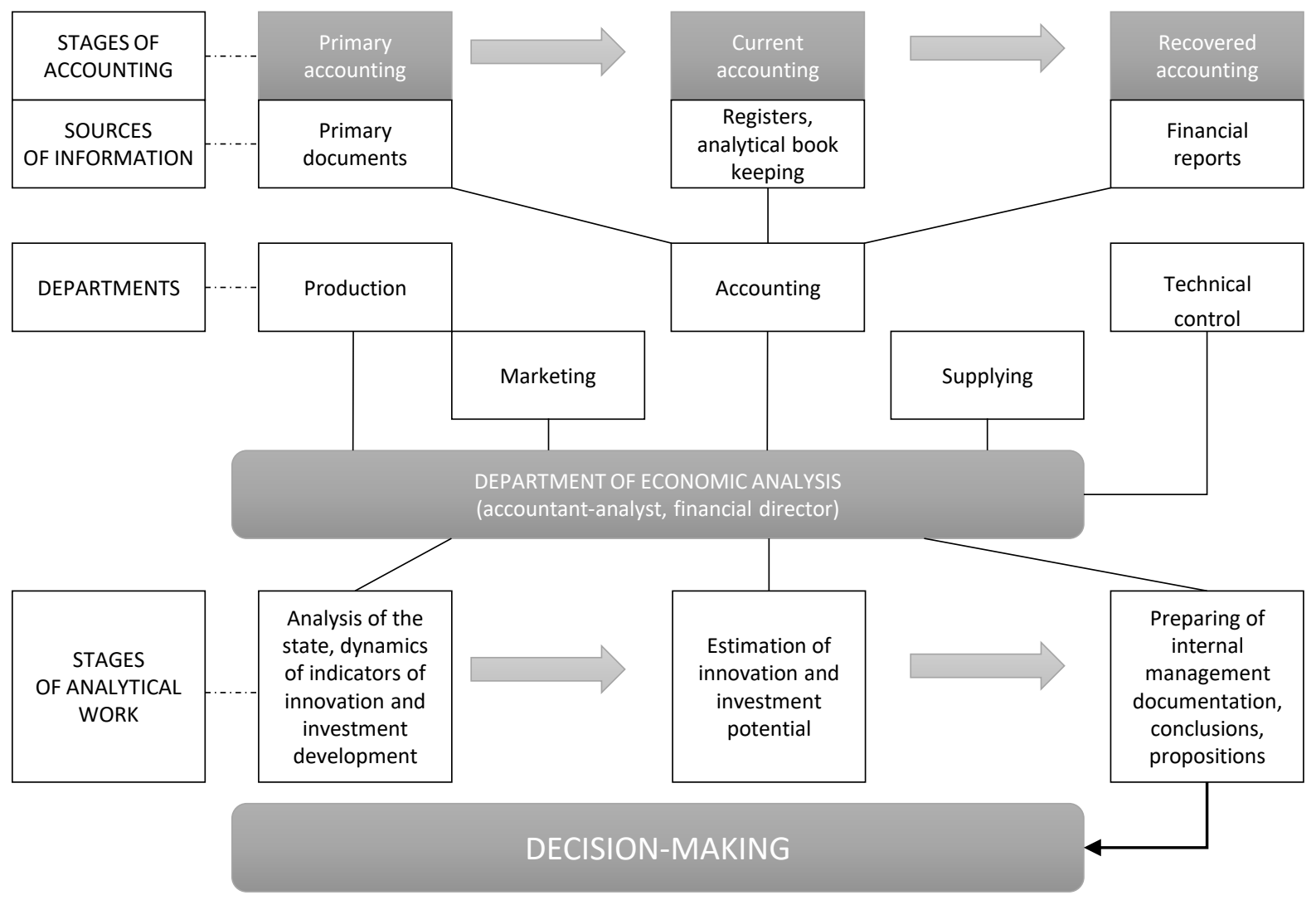

Figure 1. The scheme of formation of accounting and analytical information on innovation and investment activity of the enterprise 
Apparently, the analytical process of information processing plays an important role in this process. In order to be effective, analytical work at the large enterprise needs to be properly organized. It requires an additional material and technical base and performers, which means more spending of funds. Some accounting and analytical information comes from the heads of departments and is characterized by operational analysis of a certain area of the enterprise, meaning the department. At the enterprises, where the department of economic analysis operates well, there could be differentiated three main stages of carrying out analytical work and obtaining in the final result of accounting and analytical information.

At the first stage of the analytical process, it is necessary to draw up a plan of analytical work at the enterprise and prepare all necessary materials for the actual analysis as such. That is at this stage that the materials of the previous research are studied, and the performers are appointed.

At the second stage, there is carried out the collection (with the use of statistical reporting, data of synthetic and analytical accounting, planning documentation, results of observations, etc.) and validation of the information used. A thorough analysis of various indicators of the company's activity, the influence on them of the relevant factors, the interdependence of the indicators and their significance to ensure the growth of the profit of enterprises is carried out, the directions and reasons for the deviation of the actual values of the indicators from the forecast, as well as the reserves, increase the efficiency of the enterprise. At this stage, all possible methods and tools of economic analysis are used, including comparison, graphical, balance, elimination (the influence of each factor on the value of the investigated object), statistical, etc.

At the third stage, the results of the analysis are summarized, conclusions are drawn up, and proposals are made for improving the efficiency of the enterprise, eliminating shortcomings in the work and mobilizing unused reserves. Compulsory element of this stage is the systematic monitoring of the implementation of decisions taken in accordance with the results of the analysis.

Continuous improvement and reformation of domestic accounting, transition to International
Accounting and Reporting Standards makes it more distinct from financial and managerial, which certainly had an impact on the methodology, methods and organization of the analysis of the business activity of the enterprise.

Consequently, the place of financial and managerial analysis in the general system of economic analysis can be reflected by the following scheme (Figure 2).

On the basis of the proposed scheme (Figure 2), it looks reasonable to consider the common features and differences of each type of analysis (Table 1).

Differentiation of analysis of business activity into the external and internal is based on dividing the users into external and internal.

Internal users include owners, top managers, managers of different levels of management, and other staff who make managerial decisions. External users are investors, lenders, controlling bodies, as well as other interested entities.

The indisputable difference is in the information base of both types of analysis. As the access to the information concerning company's activity is closed, the basis of the external information analysis information is only the public financial statements of the enterprise in balance sheet, financial results statement, cash flow statement, statement of equity, and notes to the annual financial statements. Proceeding from the availability of information assurance, external analysis can only be financial, since external actors are not able to use the information necessary for managerial analysis.

Internal analysis, as a source of information, uses not only financial reports, but also a set of accounting, economic, technical and other information. Performance of internal analysis is not regulated, limited in time and is not informational. Since internal users have access to any information resources of the enterprise, the results of this analysis are confidential and are considered to be commercial secrets.

It is clear that for external and internal users, different information on the activities of the company is needed. Therefore, according to the needs of users, different aims and objectives are set before internal and external analysis. Thus, the purpose of external 


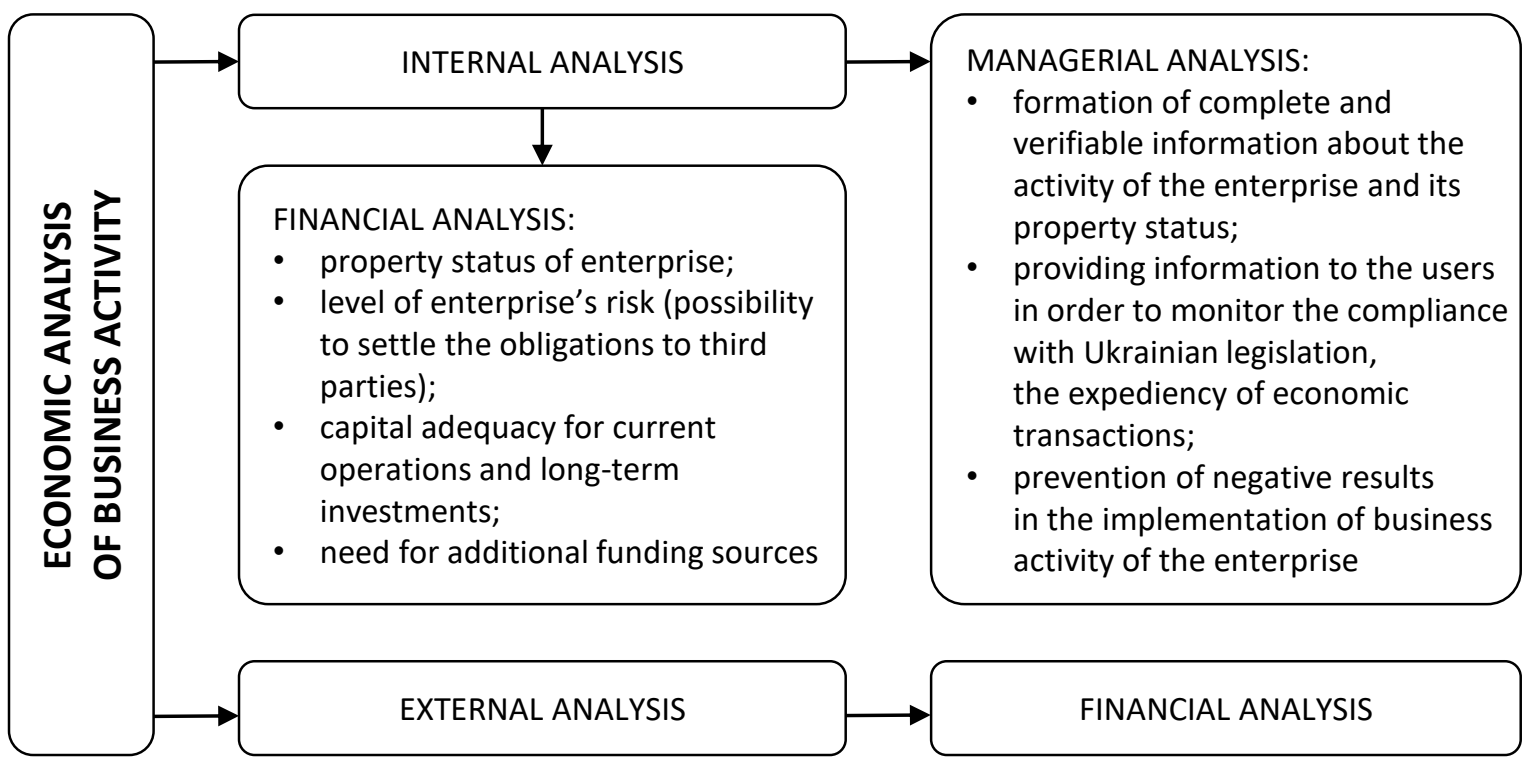

Figure 2. The scheme of displaying the place of management and financial analysis in the general system of analysis of economic activity of the enterprise

financial analysis is a general assessment of the property and financial status of the enterprise, its creditworthiness, solvency and investment attractiveness. Internal analysis is intended for top managers and managers of the enterprise, so its main purpose is to provide them with information to make managerial decisions; identify internal reserves; increase the efficiency of enterprise's activity; evaluate of the enterprise's activity and its subdivisions; define general tendencies and regularities of the environment and its influence on the activity of the enterprise; assess the enterprise strategy.

It should be noted that financial and managerial analyses, as varieties of internal analysis of business activity, have common features and, as separate types, have certain differences. The same is true for internal and external financial analysis. On the one hand, common features characterize them as one type of analysis (financial), differences - as varieties of financial analysis (external and internal).

The main difference, which is the basis for division of internal analysis into managerial and financial, is their objects, being the matter of the study. In managerial analysis, the objects are material and labor resources, their use and provision of enterprises; production and non-production costs; prime cost, quality, and volume of production.
The objects of financial analysis are cash flows, financial performance, financial position, solvency, liquidity of the enterprise, and others.

Of course, the information basis for managerial and financial analyses is also different. In managerial analysis, a large amount of accounting and off-balance information is used. For financial analysis, basically financial accounting data and financial statements are used. However, the information basis for internal financial analysis is much wider than those being used in the external financial analysis.

Besides, managerial and financial analyses have different purpose and objectives. The main purpose of managerial analysis is to provide the information for management decisions on: the provision of the company with basic assets, land, material and labor resources; production, sales, prime cost and product quality; cost behavior and break-even production; detection and development of unused reserves, etc. The internal financial analysis of the enterprise is carried out for the purpose of estimating and forecasting the financial condition of the enterprise.

Based on the stated purpose and objectives, there are revealed the functions of managerial and fi- 
Table 1. Comparative characteristic of types of economic analysis

\begin{tabular}{|c|c|c|c|c|}
\hline \multirow{2}{*}{ No } & \multirow{2}{*}{ Spheres of influence } & \multicolumn{2}{|c|}{ Internal analysis } & \multirow{2}{*}{$\begin{array}{c}\text { External analysis } \\
\text { Financial analysis }\end{array}$} \\
\hline & & Managerial analysis & Financial analysis & \\
\hline 1 & Users of information & \multicolumn{2}{|c|}{ Internal users } & External users \\
\hline 2 & Informational assurance & $\begin{array}{l}\text { Complex of economic and non- } \\
\text { economic information }\end{array}$ & $\begin{array}{l}\text { Financial statement } \\
\text { and other financial } \\
\text { information }\end{array}$ & Public financial statement \\
\hline 3 & Purpose of analysis & $\begin{array}{c}\text { Analysis of resource endowment, } \\
\text { production process, production } \\
\text { prime cost in order to make } \\
\text { managerial decisions }\end{array}$ & $\begin{array}{l}\text { Assessment of } \\
\text { financial status to plan } \\
\text { business activity of the } \\
\text { enterprise }\end{array}$ & $\begin{array}{l}\text { Assessment of financial } \\
\text { status of the enterprise } \\
\text { in regard to determine } \\
\text { its creditworthiness and } \\
\text { investment attractiveness }\end{array}$ \\
\hline 4 & Objects of analysis & $\begin{array}{l}\text { Volumes of production and sales, } \\
\text { expenditures, production prime } \\
\text { cost, resource endowment and } \\
\text { character of their use }\end{array}$ & \multicolumn{2}{|c|}{$\begin{array}{l}\text { Financial results of activity, financial status, paying } \\
\text { capacity, liquidity of the enterprise, etc. }\end{array}$} \\
\hline 5 & Use of methodology & \multicolumn{2}{|c|}{ Develop by itself or use unified methodology } & Unified methodology \\
\hline 6 & Organizational structuring & \multicolumn{2}{|c|}{ Centralized, decentralized and combined } & $\begin{array}{l}\text { Performing by auditor and } \\
\text { consulting companies }\end{array}$ \\
\hline 7 & Representation of results & $\begin{array}{l}\text { Money and organic producers, } \\
\text { coefficients }\end{array}$ & \multicolumn{2}{|c|}{ Money makers and coefficients } \\
\hline 8 & $\begin{array}{l}\text { Availability of results } \\
\text { of research }\end{array}$ & \multicolumn{2}{|c|}{ Confidential information } & Public information \\
\hline
\end{tabular}

nancial analyses. Thus, the main function of managerial analysis is diagnostic, which consists in identifying the causes of changes that arise in the process of business activity and measuring the influence of factors on these changes; searching there are revealed unused reserves and opportunities for further development of the enterprise. In the process of financial analysis, the evaluation function is implemented - meaning that the state of the enterprise is determined, and the searching - there are revealed potential opportunities for fifi nancial growth.

Regarding the management process, managerial analysis is clearly operational, and financial - rety rospective. The financial analysis, which is mainly based on the financial statements, reveals the lost opportunities and errors that have been made during the year and at the time of their discovery have lost their significance. Nevertheless, both managerial and financial analyses are essential for assessing the future performance of a business and allow them to receive both retrospective and strategically oriented information.

Understanding the problem of organizing economic analysis is objectively due to the fact that the organization is closely linked with the methodology of conducting analytical studies, the use of computer facilities in economic work, organizational structure of management, a system for monitoring the imple- mentation of the results of analysis. Each individual case reveals an organization on the one and only hand; therefore, its holistic characterization is possible only through a comprehensive study of its various connections. It requires the substantiation of approaches that would ensure the rational organization of analytical work.

The organizational structure of both managerial and financial analyses can be centralized (separate departments of economic analysis are created in the management structure), decentralized (the complex of analytical works is distributed in the operating system of management) or combined (combining both forms). However, managerial analysis, especially in large enterprises, is often organized by the centers of responsibility (income center and cost center).

An important distinctive difference between managerial and financial analyses is the use of techniques used in the process of their implementation. The main methods of conducting managerial analysis are: analysis of break-even; margin analysis; cost behavior analysis; analysis of budget execution and others.

Financial analysis is carried out using the following methods: express analysis of financial condition; analysis of financial coefficients; factor financial analysis. 


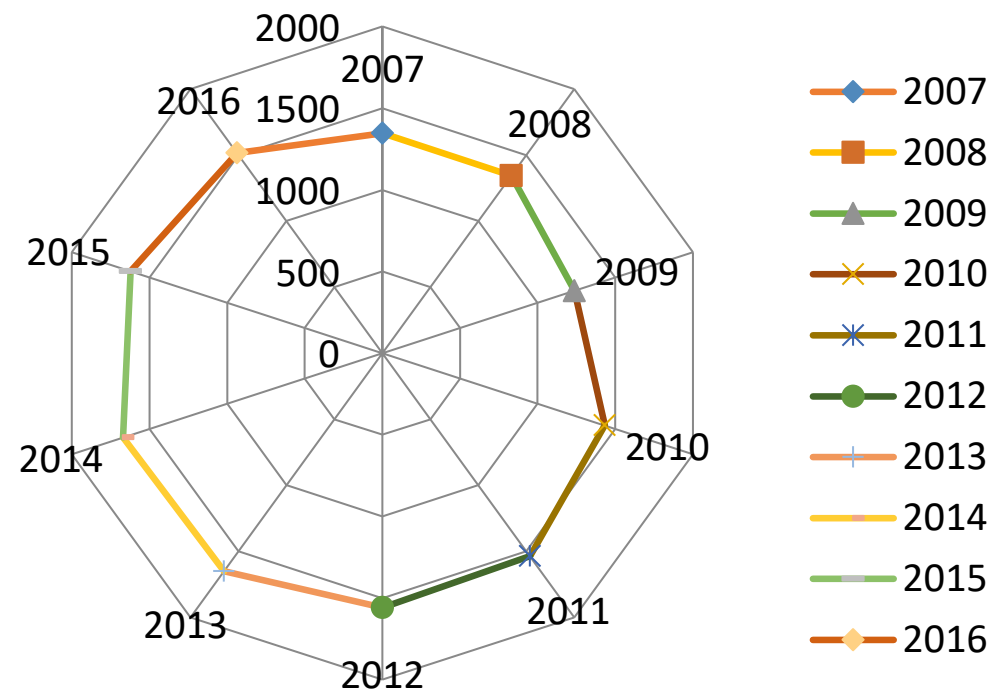

Figure 3. Dynamic tendencies of steel production

Managerial and financial analyses have a significant impact on the study of operational activities of metallurgical enterprises. With these types of analysis, one can determine the rates of economic growth and the availability of investment resources. Using them in the work of metallurgical enterprises will lead to a deeper study of both operational and financial and investment activities, which in turn will increase the innovation and investment development of such enterprises and increase competitiveness on the world market.

Metallurgical production is the leading industry in Ukraine. In the structure of the economy, $36 \%$ belongs to metallurgical industry. The leading role of metallurgy in shaping the GDP of the country is confirmed by the International Steel Association (World Steel Association). According to its data, Ukraine is in the 10th place, producing 24 million tons of steel (in 2016). Let us consider the trends on the example of steel production (Figure 3, Table 2).

According to statistics, resuming the results of January, China has traditionally maintained the leadership in the ranking of world steel producers with an index of 67.2 million tons (up to $7.4 \%$ by January 2016).

Further, the countries in the top ten ranking have been placed in the following order: Japan ( 9 million tons, $+2.7 \%)$, India $(8,4$ million tons, $+12 \%)$,
USA (6,9 million tons, $+6.5 \%)$, Russia $(6,2$ million tons, $+11.6 \%$ ), South Korea (5,9 million tons, $+3.2 \%)$, Germany (3,6 million tons, $+1.2 \%)$, Turkey $(2,9$ million tons, $+12.8 \%)$ and Brazil $(2,8$ million tons, $+14.4 \%)$

The third part of all steel in the world is produced by 10 global world corporations: ArcelorMittal, Hesteel Group, NSSMC, POSCO, Baosteel Group, Shagang Group, Ansteel Group, JFE Steel Corporation, Shougang Group, Tata Steel Group. $50 \%$ of corporations - the biggest producers of steel - belongs to China, $20 \%$ - to Japan, $10 \%$ - to South Korea, that is to say almost $80 \%$ of corporations are located in Asia. Dynamics of steel production by the world corporations for the last 5 years is presented in Table 2 .

Analyzing Table 2, it should be noted that the rating of metallurgical enterprises mostly depends on the status of the material and technical base. In comparison with the average degree of depreciation of fixed assets in the industry in 2015, metallurgical enterprises showed a much better indicator - $41.2 \%$ (Table 4 ) in comparison with $2016-54.9 \%$, although in developed countries, particularly in the USA, it ranges from 15 to $25 \%$. However, the pace of equipment upgrade is rather slow, even in the pre-crisis period they did not exceed $8 \%$, thus forming a 13-year cycle of renewal of fixed assets. The global financial crisis and its subsequent socio-economic crisis 
Table 2. Dynamics of steel production by the world corporations

Source: The World Steel Association. Retrieved from https://www.worldsteel.org/

\begin{tabular}{|c|c|c|c|c|c|c|c|c|}
\hline $\begin{array}{l}2015 \\
\text { rank }\end{array}$ & $\begin{array}{l}2016 \\
\text { rank }\end{array}$ & Companies & Country & 2012 & 2013 & 2014 & 2015 & 2016 \\
\hline 1 & 1 & ArcelorMittal & Luxemburg & 93.58 & 96.10 & 98.09 & 97.14 & 95.45 \\
\hline 2 & 2 & China Baowu Grup & China & 79.12 & 83.22 & 76.40 & 60.71 & 63.81 \\
\hline 3 & 3 & $\begin{array}{l}\text { Hesteel Group (Hebei Iron and Steel Co } \\
\text { Ltd) }\end{array}$ & China & 42.84 & 45.79 & 47.10 & 47.75 & 46.18 \\
\hline 4 & 4 & $\begin{array}{l}\text { Nippon Steel and Sumitomo Metal } \\
\text { Corporation (NSSMC) }\end{array}$ & Japan & 47.86 & 50.13 & 49.30 & 46.37 & 46.18 \\
\hline 5 & 5 & POSCO & South Korea & 39.88 & 38.41 & 41.60 & 41.98 & 41.56 \\
\hline 6 & 6 & Shagang Group & China & 32.31 & 35.09 & 35.33 & 34.21 & 33.25 \\
\hline 7 & 7 & Ansteel Group & China & 30.23 & 33.69 & 34.35 & 32.50 & 33.19 \\
\hline 8 & 8 & JFE Steel Corporation & Japan & 30.41 & 31.16 & 31.41 & 29.83 & 30.29 \\
\hline 9 & 9 & Shougang Group & China & 31.42 & 31.52 & 30.78 & 28.55 & 26.80 \\
\hline 10 & 10 & Tata Steel Group & India & 22.97 & 25.27 & 26.20 & 26.31 & 24.49 \\
\hline 40 & 37 & Metinvest Holding LLC & Ukraine & 14.34 & 14.30 & 11.18 & 9.65 & 10.34 \\
\hline 65 & 74 & ISD & Ukraine & 8.49 & 7.94 & 6.03 & 4.80 & 4.61 \\
\hline
\end{tabular}

have considerably reduced the investment opportunities of enterprises, which manifested itself in reducing the rate of renewal of fixed assets to $2-3 \%$ per annum.

The investment development of the metallurgical industry is ensured by the introduction of resource-saving technologies. Today, Ukrainian metallurgical enterprises consume on average 4.8 times more energy per ton of steel than in Poland, 9 times more than in Turkey and 11-12 times more than in the USA. In the structure of energy balance of Ukrainian metallurgical enterprises, natural gas takes $15 \%$ as of 2015 . At the same time, most steel producing countries have abandoned valuable natural gas in favor of coal-fired fuel technology, which is not only cheaper, but also environmentally friendly.
Solving the problems of the mining and metallurgical complex requires significant investment expenditures with rather high payback periods 5 years or more. Considering political instability and economic crisis, investors consider long-term investments as too risky. Prior to the crisis of 2014, the metallurgy industry was in a more favorable position than other sectors of the economy, with the exception of grain crops, in terms of attracting investment, due to its export-oriented nature. In the last nine years, it ranks third in terms of capital investment after the energy industry and the food industry. In the period 2014-2016, the dynamics of capital investment, as opposed to another key industry sector, which is more oriented towards domestic consumption - machine building, remained positive, but due to inflation, the real cost of received funds decreased by $40 \%$ (Table 4 ).

Table 3. Fixed assets of metallurgical industry in Ukraine

Source: State Statistics Service (2016). Scientific and innovative activity in Ukraine. Statistical bulletin. Kyiv. Retrieved from http://www.ukrstat.gov.ua

\begin{tabular}{|c|c|c|c|c|c|c|c|c|c|}
\hline Indicators & 2008 & 2009 & 2010 & 2011 & 2012 & 2013 & 2014 & 2015 & 2016 \\
\hline $\begin{array}{l}\text { Cost of fixed assets at } \\
\text { the end of the year, UAH } \\
\text { million }\end{array}$ & 103271 & 132570 & 138210 & 254009 & 247685 & 181908 & 196804 & 235184 & 295825 \\
\hline $\begin{array}{l}\text { Level of depreciation of } \\
\text { fixed assets, \% }\end{array}$ & 62.4 & 59.5 & 59.3 & 63.3 & 63.0 & 44.7 & 41.2 & 41.2 & 54.9 \\
\hline $\begin{array}{l}\text { Implementing of fixed } \\
\text { assets into action, UAH } \\
\text { million }\end{array}$ & 7849 & 5375 & 3296 & 5080 & 6686 & 11876 & 3944 & 7571 & 7147 \\
\hline $\begin{array}{l}\text { Coefficient of renewal, } \\
\text { items }\end{array}$ & 0.076 & 0.041 & 0.024 & 0.020 & 0.027 & 0.065 & 0.020 & 0.032 & 0.024 \\
\hline
\end{tabular}


Table 4. Innovative activity of metallurgical enterprises

\begin{tabular}{|c|c|c|c|}
\hline Indicators & 2014 & 2015 & 2016 \\
\hline \multicolumn{4}{|c|}{ Characteristic of enterprises which carried out innovative activity } \\
\hline $\begin{array}{l}\text { Quantity of enterprises which carried out innovative activity (as for the areas of } \\
\text { innovative activities), items }\end{array}$ & 138 & 65 & 73 \\
\hline \multicolumn{4}{|l|}{ among them funds were spent } \\
\hline on internal scientific researches & 23 & 13 & 21 \\
\hline on external scientific researches & 15 & 11 & 18 \\
\hline on purchasing machines, equipment and software & 78 & 40 & 53 \\
\hline other external knowledge & 7 & 1 & 10 \\
\hline studying and preparing of staff & 22 & - & - \\
\hline market implementing of innovations & 4 & - & - \\
\hline Other & 10 & 16 & 28 \\
\hline Quantity of industrial enterprises which implemented innovations, items & 110 & 54 & 72 \\
\hline implemented innovative processes & 41 & 36 & 53 \\
\hline among them low-waste and resource-saving & 10 & 17 & 28 \\
\hline implemented innovative types of products & 55 & 36 & 58 \\
\hline among them new for the market & 13 & 7 & 15 \\
\hline Quantity of industrial enterprises, which realized innovative products, items & 82 & 44 & 65 \\
\hline products, new for the market & 15 & 8 & 16 \\
\hline products, new only for the enterprise & 74 & 41 & 53 \\
\hline \multicolumn{4}{|l|}{ Funding of innovation activity } \\
\hline Total sum of expenses as for areas of innovative activity, UAH thousand & 466573,8 & 7901345,5 & 14478748,6 \\
\hline including internal scientific researches & 51727,9 & 15046,4 & 36616,5 \\
\hline external scientific researches & 5021,1 & 6184,7 & 135673,3 \\
\hline purchasing machines, equipment and software & 279458,9 & 7868031 & 13980968,1 \\
\hline other external knowledge & 118,3 & 19,0 & 5487,3 \\
\hline Other & 130247,6 & 12064 & 320003,4 \\
\hline Total volume of funding innovative activity, UAH thousand & 466573,8 & 7901345,5 & 14478748,6 \\
\hline \multicolumn{4}{|l|}{ including those by means of } \\
\hline own sources & 436510,5 & 7891688,5 & 14264074,1 \\
\hline state budget & 3975 & - & 125710,0 \\
\hline local budgets & - & 106,6 & - \\
\hline extrabudgetary resources & - & - & - \\
\hline domestic investors & 41,6 & 11,7 & 3571,6 \\
\hline foreign investors & 14172,7 & 27,2 & - \\
\hline Credits & 11874 & 9511,5 & 3027,6 \\
\hline other sources & - & - & - \\
\hline \multicolumn{4}{|l|}{ Results of innovation activity } \\
\hline Quantity of item names of implemented innovative types of products, items & 354 & 324 & 482 \\
\hline Quantity of implemented new technological processes, items & 320 & 122 & 389 \\
\hline
\end{tabular}

Innovation activity of metallurgical enterprises is financed at the expense of its own sources in 95$99 \%$ of cases. The results of innovation activity also have declining tendencies of development. The volume of implemented innovative products de- by almost UAH 1 billion. 


\section{CONCLUSION}

Interconnection of managerial and financial analyses is particularly manifested when conducting the comprehensive analysis of the business activity of the enterprise and the industry as a whole; performance appraisal; substantiation of norms, target programs and business plans; making marketing analysis; analysis of production and sales of products. Comprehensive use of the entire information basis enables to solve the list of tasks that are put before the analysis more effectively, to identify shortcomings in the work of the company and the direction of increasing its efficiency.

Considering the abovementioned, it should be argued that the differentiation of the economic analysis of the enterprise's business activity into managerial and financial is not fictitious but follows from its methodology. Therefore, managerial and financial analyses should be considered and studied as separate types having their objects, information basis, purpose, corresponding tasks and methods of performing. The study of these types of analysis separately will allow to improve organizational, informational and methodological assurance, based on methodological approaches and considering practical needs. It should be borne in mind that managerial and financial analyses are closely interconnected among themselves as varieties of internal analysis of business activity and deepen and complement each other in the implementation of complex and other types of analysis.

The conducted analysis allows to conclude that notwithstanding some positive changes in the implementation of innovative technologies in the most successful metallurgical enterprises in Ukraine, the industry as a whole is characterized by a high degree of technological lag, which makes metallurgy production very sensitive to fluctuations in demand on the international market - meaning its reduction and release of production capacity in more competitive market participants. Also, a full-scale modernization of the metallurgical industry requires significant investment funds. Therefore, the existing problems cannot be solved effectively without the state assistance, without public-private partnerships and activities to stimulate innovation and investment development of metallurgical enterprises.

\section{REFERENCES}

1. Borodkin, O. (2001). Внутрішньогосподарський (управлінський) облік. Концепція і організація [Vnutrishnohospodarskyi (upravlinskyi) oblik. Kontseptsiia i orhanizatsiia]. Bukhhalterskyi oblik i audyt, 2.

2. Boronos V. H., Vasyleva, T. А. (Ed.) (2009). Проблеми фінансового забезпечення інноваційного розвитку [Problemy finansovoho zabezpechennia innovatsiinoho rozvytku] (351 p.). Sumy: SumDU.

3. Druker, P. F. (2008). Бизнес и инновации [Biznes $\mathrm{i}$ innovatsii] (432 p.). Moscow: Vilyams.

4. Dykha, M. V., Tanasiienko, N. P., \& Kolisnyk, G. M. (2017). Ensuring of labor productivity growth in the context of investment and innovation activity intensification.
Problems and Perspectives in Management, 15(4), 197-208. http:// dx.doi.org/10.21511/ppm.15(41). 2017.04

5. Fatkhutdinov, R. A. (2002). Инновационный менеджмент [Innovatsionnyi menedzhment] (400 p.). Saint Petersburg: Piter.

6. Heiets, V. M. (2006). Нестабільність та економічні зростання [Nestabilnist ta ekonomichni zrostannia] (344 p.). Kyiv: Instytut ekonomichnykh prohnozuvan.

7. Keyns, Dzh. M. (1999). Общая теория занятости, проиента и денег [Obshchaya teoriya zanyatosti, protsenta i deneg] (451 p.). Moscow: Gelios ARV.

8. Kindratska, H. I., Bilyk, M. S., Zahorodnii, A. H. (Ed.) (2006). Економічний аналіз: теорія $i$ практика [Ekonomichnyi analiz: teoriia i praktyka] (428 p.). Lviv: Mahnoliia Plius.

9. Koval, V. V., Kryvonogova, I. G., Muzhailo, V. D. (2017). Підвищення інноваційноінвестиційної активності підприємств металургійної галузі України [Pidvyshchennia innovatsiino-investytsiinoi aktyvnosti pidpryiemstv metalurhiinoi haluzi Ukrainy]. Ekonomika ta upravlinnia pidpryiemstvamy, 11, 238-243. Retrieved from http:// www.economyandsociety.in.ua/ journal-11/18-stati-11/1217koval-v-v-krivonogova-i-g-muzhajlo-v-d

10. Lakhtianova, L. A. (2004).

Фінансовий аналіз сільськогосподарських nідприємств [Finansovyi analiz silskohospodarskykh pidpryiemstv] (365 p.). Kyiv: KNEU. 
11. Lipsits, I. V., Kossov, V. V. (1996). Инвестиционный проект: методы подготовки и анализа [Investitsionnyy proekt: metody podgotovki i analiza] (304 p.). Moscow: BEK.

12. Medynskyi, V. H., Sharukova, L. H. (1997). Інноваційне підприємництво [Innovatsiine pidpryiemnytstvo] (240 p.). Moscow: INFRA-M.

13. Mishenin, E. V., Semenenko, B. A., Mishenina, N. V. (1996). Экономический механизм экологизации производства [Ekonomicheskiy mekhanizm ekologizatsii proizvodstva] (140 p.). Sumy: IPP, “Mriia-1 LTD”.

14. Mnykh, Ye. V. (2005). Економічний аналіз [Ekonomichnyi analiz] (472 p.). Kyiv: Tsentr navchalnoi literatury.

15. Popovych, P. Y. (2004) Економічний аналіз діяльності суб'єктів господарювання [Ekonomichnyi analiz diialnosti subiektiv hospodariuvannia] (416 p.). Ternopil: Ekonomichna dumka.

16. Resler, M. V. (2017). Accounting and analytical support for innovation process. Scientific Journal of Polissia, 1(9), 54-60. Retrieved from http://journals. uran.ua/nvp_chntu/article/ view/101831/97035

17. Reznikova, O. S. (2014). Перспективи розвитку металургійних підприємств України в умовах глобальної конкуренції [Perspektyvy rozvytku metalurhiinykh pidpryiem- stv Ukrainy v umovakh hlobalnoi konkurentsii]. Intelekt XXI, 3 54-63.

18. Sahal, D. (1985). Технический прогресс: кониепиии, модели, оценки [Tekhnicheskiy progress: kontseptsii, modeli, otsenki] (223 p.). Moscow: Finansy i statistika.

19. Sharupov, O. O. (2017). Аналіз сучасних тенденцій у металургії: інноваційнийінвестиційний розвиток та конкурентоспроможність на світовому ринку [Analiz suchasnykh tendentsii u metalurhii: innovatsiino-investytsiinyi rozvytok ta konkurentospromozhnist na svitovomu rynku]. Naukovyi visnyk Uzhhorodskoho natsionalnoho universytetu, 11, 168-173.

20. Sheremet, A. D. (2002). Теория экономического анализа [Teoriya ekonomicheskogo analiza] (333 p.). Moscow: INFRA-M.

21. Shtuler, I., Cherlenyak, I., Domyshche-Medyanik, A., \& Voitovych, S. (2017). Conditions of formation and stimulation of the activators of innovative development of Ukraine. Problems and Perspectives in Management, 15(4), 150-160. http://dx.doi. org/10.21511/ppm.15(4).2017.13

22. Shumpeter, I. A. (2008). Теория экономического развития [Теоriya ekonomicheskogo razvitiya] (112 p.). Moscow: Direktmedia pablishing.

23. State Statistics Service (2016). Scientific and innovative activity in Ukraine. Statistical bulletin.
Kyiv. Retrieved from http://www. ukrstat.gov.ua

24. Statistic Service of European Union (Eurostat) (n.d.). Official website. Retrieved from http:// ec.europa.eu/eurostat/web/main/ home

25. Sudarieva, L. O. (2005).

Облік, контроль і аналіз у міжнародному бізнесі: управлінський аспект [Oblik, kontrol i analiz u mizhnarodnomu biznesi: upravlinskyi aspekt] (213 p.). Donetsk: Don duet.

26. Svichkar, V. K. (1999). Управлінський економічний аналіз [Upravlinskyi ekonomichnyi analiz] (82 p.). Donetsk: IEP NAN Ukrainy.

27. Tviss, В. (1989). Управление научно-техническими нововведениями [Upravlenie nauchno-tekhnicheskimi novovvedeniyami] (271 p.). Moscow: Ekonomika.

28. Worldsteel Association (n.d.). Retrieved from https://www. worldsteel.org/

29. Верховна Рада України [Verkhovna Rada Ukrainy] (2002). Закон України про інноваційну діяльність (Закон від 04.07.2002 № 40-IV) [Zakon Ukrainy pro innovatsiinu diialnist (Zakon vid 04.07.2002 No. 40-IV)]. Kyiv.

30. Державна Служба Статистики України [Derzhavna Sluzhba Statystyky Ukrainy] (2016). Промисловість України у 20112015 pp. [Promyslovist Ukrainy u 2011-2015 rr]. Kyiv: DSSU. 